\title{
The development and application of new crystallization method for tobacco mosaic virus coat protein
}

\author{
Xiangyang Li, Baoan Song ${ }^{*}$, Deyu Hu, Zhenchao Wang, Mengjiao Zeng, Dandan Yu, Zhuo Chen, Linhong Jin \\ and Song Yang*
}

\begin{abstract}
Background: Although tobacco mosaic virus (TMV) coat protein (CP) has been isolated from virus particles and its crystals have grown in ammonium sulfate buffers for many years, to date, no one has reported on the crystallization of recombinant TMV-CP connecting peptides expressed in E. coli.

Methods: In the present papers genetically engineered TMV-CP was expressed, into which hexahistidine (His) tags or glutathione-S-transferase (GST) tags were incorporated. Considering that GST-tags are long peptides and His-tags are short peptides, an attempt was made to grow crystals of TMV-CP cleaved GST-tags (WT-TMV-CP 32 ) and TMV-CP incorporated His-tags (WT-His-TMV-CP 12 ) simultaneously in ammonium sulfate buffers and commercial crystallization reagents. It was found that the $20 \mathrm{~S}$ disk form of WT-TMV-CP 32 and WT-His-TMV-CP 12 did not form high resolution crystals by using various crystallization buffers and commercial crystallization reagents. Subsequently, a new experimental method was adopted in which a range of truncated TMV-CP was constructed by removing several amino acids from the $\mathrm{N}$ - or the C-terminal, and high resolution crystals were grown in ammonium sulfate buffers and commercial crystallization reagents.
\end{abstract}

Results: The new crystallization method was developed and $3.0 \AA$ resolution macromolecular crystal was thereby obtained by removing four amino acids at the C-terminal of His-TMV-CP and connecting six His-tags at the $\mathrm{N}$-terminal of His-TMV-CP (TR-His-TMV-CP 19 ). The Four-layer aggregate disk structure of TR-His-TMV-CP 19 was solved. This phenomenon showed that peptides at the C-terminus hindered the growth of high resolution crystals and the peptides interactions at the $\mathrm{N}$-terminus were attributed to the quality of TMV-CP crystals.

Conclusion: A 3.0 A resolution macromolecular crystal of TR-His-TMV-CP 19 was obtained and the corresponding structure was solved by removing four amino acids at the C-terminus of TMV-CP and connecting His-tags at the $\mathrm{N}$-terminus of TMV-CP. It indicated that short peptides influenced the resolution of TMV-CP crystals.

Keywords: GST-tags, His-tags, Peptides, Disk form, Protein crystals, TMV-CP, Truncated protein

\section{Background}

Tobacco mosaic virus (TMV) has a rod-like appearance and consists of a single, positive strand RNA of 6395 nucleotides encapsulated in a helical virion by approximately 2130 identical coat protein $(\mathrm{CP})$ subunits [1-7]. $\mathrm{CP}$ consists of 158 amino acids that were assembled into

\footnotetext{
*Correspondence: songbaoan22@yahoo.com; fcc.syang@ gzu.edu.cn State Key Laboratory Breeding Base of Green Pesticide and Agricultural Bioengineering, Key Laboratory of Green Pesticide and Agricultural bioengineering of Ministry of Education, Guizhou University, Huaxi District, Guiyang 550025, Guizhou Province, P. R China
}

four main alpha-helices joined by a prominent loop proximal to the axis of the virion [8-16]. TMV-CP played an important role in the self-assembly of TMV through an initial RNA recognition reaction that triggers the assembly, it was believed to be necessary for virus assembly initiation and elongation [8,17-24]. The biological physical properties of TMV-CP were often determined by the structure of TMV. The TMV structure reported in 1986 was studied based on an electron density map at $3.6 \AA$ resolution by X-ray fiber diffraction [9], and then this structure of the complete virus was
C Biomed Central 


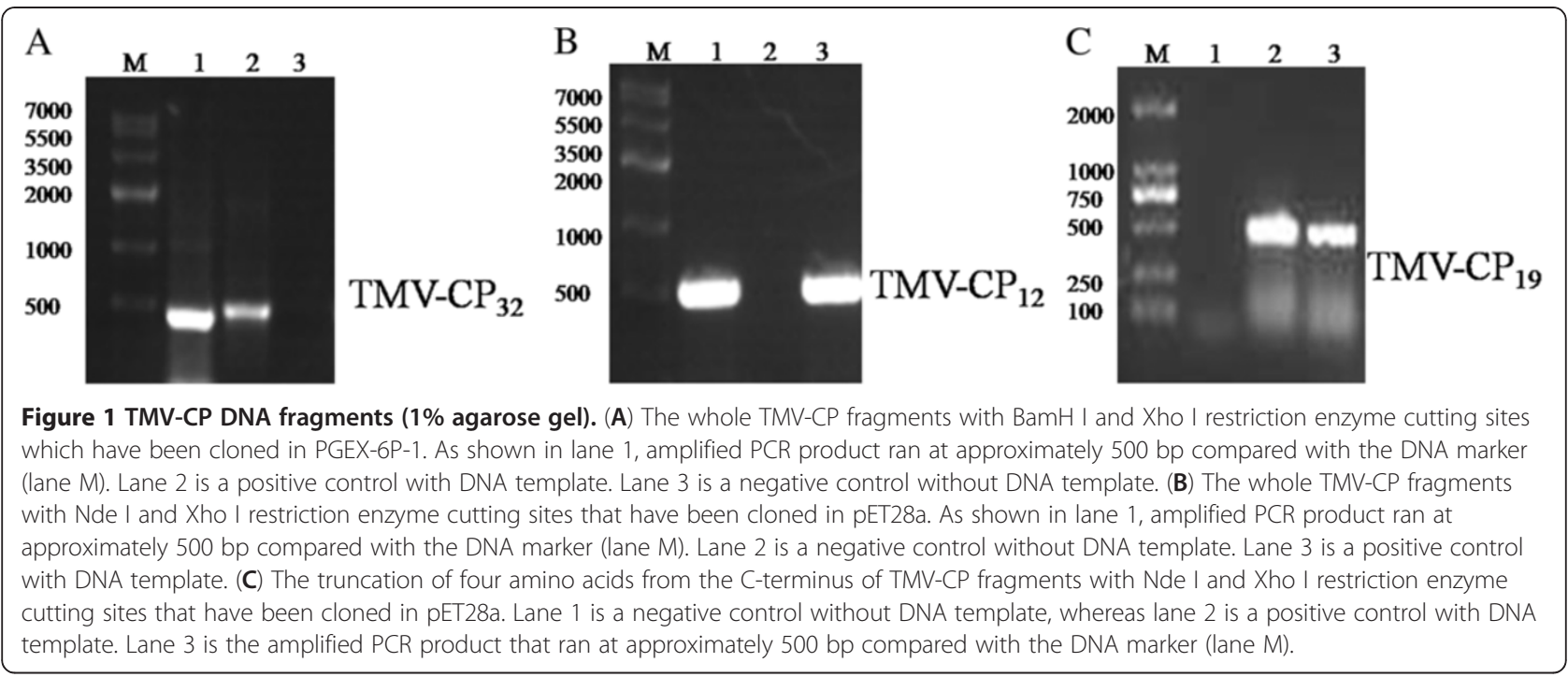

determined at $2.9 \AA$ resolution by X-ray fiber diffraction methods [25]. TMV-CP assembly systems, consisting of 34-subunit aggregate of TMV-CP crystallized as a dimer of bilayer disks having 17 subunits per layer, were crystallized and solved at $2.8 \AA$ resolution [2]. The crystalline structure of the Four-layer aggregate of TMV-CP was determined at $2.4 \AA$ resolution by using X-ray diffraction from crystals maintained at cryogenic temperatures. This structure emphasized the importance of water in biological macromolecular assemblies [22,23]. The circular permutants of TMV-CP were crystallized and solved by molecular replacement at $3.0 \AA$ resolution by using X-ray diffraction [26]. The structure of TMV was also obtained by using high resolution transmission electron microscopy [27-29].
TMV-CP was usually propagated and isolated from Nicotiana tabacum (N. tabacum) infected by TMV, and TMV-CP existed as a number of aggregates, depending on $\mathrm{PH}$, ionic strength, temperature, protein concentration, and other factors [5,12,14-21]. At $0.1 \mathrm{~mol} / \mathrm{L}$ ionic strength orthophosphate solution and $\mathrm{pH}$ equal to or greater than 8.0, TMV-CP existed as protein $\mathrm{A}$ or $4 \mathrm{~S}$ protein (a dynamic equilibrium between monomers, trimers, and pentamers of TMV-CP). At $0.1 \mathrm{~mol} / \mathrm{L}$ ionic strength orthophosphate solution and $\mathrm{pH}$ near 7.0, TMV-CP was transformed into the $20 \mathrm{~S}$ aggregate form (disks consisting of 34 monomers, also named as the $20 \mathrm{~S}$ structure) with an admixture of $4 \mathrm{~S}$ protein [30-33]. At $0.1 \mathrm{~mol} / \mathrm{L}$ ionic strength orthophosphate solution and $\mathrm{pH}$ equal to or less than 6.0, TMV-CP was completely
TR-His-TTV-CP68 TR-His-T7V-CP62 TR-His-TMV-CP19 WT-His-TTV-CP WT-TTV-CP WT-TMV-CP32

TR-His-THV-CP68 TR-His-T7VV-CP62 TR-His-TTV-CP19 UT-His-TNV-CP WT-TMV-CP WT-TMV-CP32

TR-His-THV-CP68 TR-His-TTV-CP62 TR-His-THV-CP19 WT-His-THV-CP WT-THV-CP WT-TIV-CP32
MGSSHHHHHHSSGLVPRGSHM---ITTPSQFVFLSSAWADPIELINLCTNALGNQFQTQQ 57 MGSSHHHHHHSSGLVPRGSHM---ITTPSQFVFLSSAWADPIELINLCTNALGNQFQTQO 57 MGSSHHHHHHSSGLVPRGSHMSYSITTPSOFVFLSSAWADPIELINLCTNALGNOFOTOQ 60 MGSSHHHHHHSSGLVPRSHMSYSITTPSQFVFLSSAWADPIELINLCTNALGNQFQTQO 60

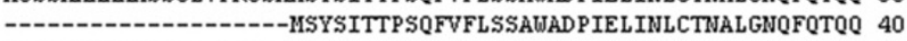
-

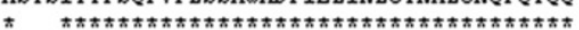

ARTVVQROFSEVUKPSPQVTVRFPDSDFKVYRYNAVLDPLVTALLGAFDTRNRIIEVENQ 117 ARTVVQRQFSEVUKPSPQVTVRFPDSD FKVYRYNAVLDPLVTALLGAFDTRNRIIEVENQ 117 ARTVVOROFSEVUKPSPQVTVRFPDSD FKVYRYNAVLDPLVTALLGAFDTRNRIIEVENO 120 ARTVVQRQFSEVIKPSPQVTVRFPDSDFKVYRYNAVLDPLVTALLGAFDTRNRIIEVENO 120 ARTVVQRQFSEVUKPSPQVTVRFPDSDFKVYRYNAVLDPLVTALLGAFDTRNRIIEVENO 100 ARTVVQRQFSEVUKPSPQVTVRFPDSDFKVYRYNAVLDPLVTALLGAFDTRNRIIEVENQ 100

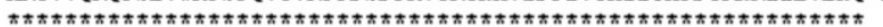

ANPTTAETLDATRRVDDATVAIRSAINNLIVELIRGTGSYNRSSFESSSGLVWT----- 171 ANPTTAETLDATRRVDDATVAIRSAINNLIVELIRGTGSYNRSSFESSSGLVWTS---- 172 ANPTTAETLDATRRVDDATVAIRSAINNLIVELIRGTGSYNRSSFESSSGLVWTS---- 175 ANPTTAETLDATRRVDDATVAIRSAINNLIVELIRGTGSYNRSSFESSSGLVWTSGPAT 179 ANPTTAETLDATRRVDDATVAIRSAINNLIVELIRGTGSYNRSSFESSSGLVWTSGPAT 159 ANPTTAETLDATRRVDDATVAIRSAINNLIVELIRGTGSYNRSSFESSSGLVTTSGPAT 159

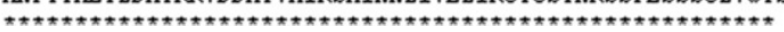

Figure 2 Alignment of the TMV-CP Sequences, the identical residues were marked below by an asterisk. 
transformed into macroscopic aggregate. The 34-subunit disk was virtually crystallized at $1.0 \mathrm{~mol} / \mathrm{L}$ ionic strength solution and $\mathrm{PH}$ near $8.0[2,3,12,17,19-21,30,31]$. The crystals of TMV-CP consisting of Four-layer aggregates were usually obtained at $3.5-14 \mathrm{mg} / \mathrm{mL}$ protein concentration $(10 \mathrm{mmol} / \mathrm{L}$ orthophosphate, $\mathrm{pH} 7.2)$ and in crystallization pool solutions consist of $0.2-0.3 \mathrm{~mol} / \mathrm{L}$ ammonium sulfate and $0.1 \mathrm{~mol} / \mathrm{L}$ Tris at $\mathrm{pH} 8.0$ for 3 wk to $4 \mathrm{wk}$ at room temperature [23]. The crystals were obtained after been equilibrated overnight against a crystallization pool solution consisting of $0.3 \mathrm{~mol} / \mathrm{L}$ ammonium sulfate and $0.1 \mathrm{~mol} / \mathrm{L}$ Tris at $\mathrm{pH} 8.0$ by microdialysis method [23,31-36]. The aformentioned method of obtaining TMV-CP from TMV will take investigators a lot of work and time, and the TMV-CP structures obtained from TMV were aggregate forms [32-36], they could not be easily modified. In this sense, by employing the method of genetically engineered, recombination TMV-CP was expressed, purified and crystallized [37-43].
In the present investigation, the genetically engineered structure of TMV-CP was the concern: a series of the recombinant expression vectors contained TMV-CP genes were constructed and transformed into E.coli, and the recombinant protein of TMV-CP were expressed, and $3.0 \AA$ resolution TR-His-TMV-CP ${ }_{19}$ (incorporated Histags at the N-terminus of TMV-CP and truncated four amino acids at the C-terminus of TMV-CP) macromolecular crystals were obtained.

\section{Results and Discussions}

\section{Identification to Recombinant Vectors}

TMV-RNA has been isolated from TMV particles (propagated in $N$. tabacum $\mathrm{K}_{326}$ ) and reverse transcribed into cDNA by primer $_{\mathrm{cDNA}}$ and reverse transcriptase (TaKaRa). The genetic fragment of wild type TMV-CP (WT-GST-TMV-CP ${ }_{32}$, with the restriction enzymes of BamH I/Xho I; WT-His-TMV-CP 12 , with the restriction enzymes of Nde I/Xho I; ) were amplified by using

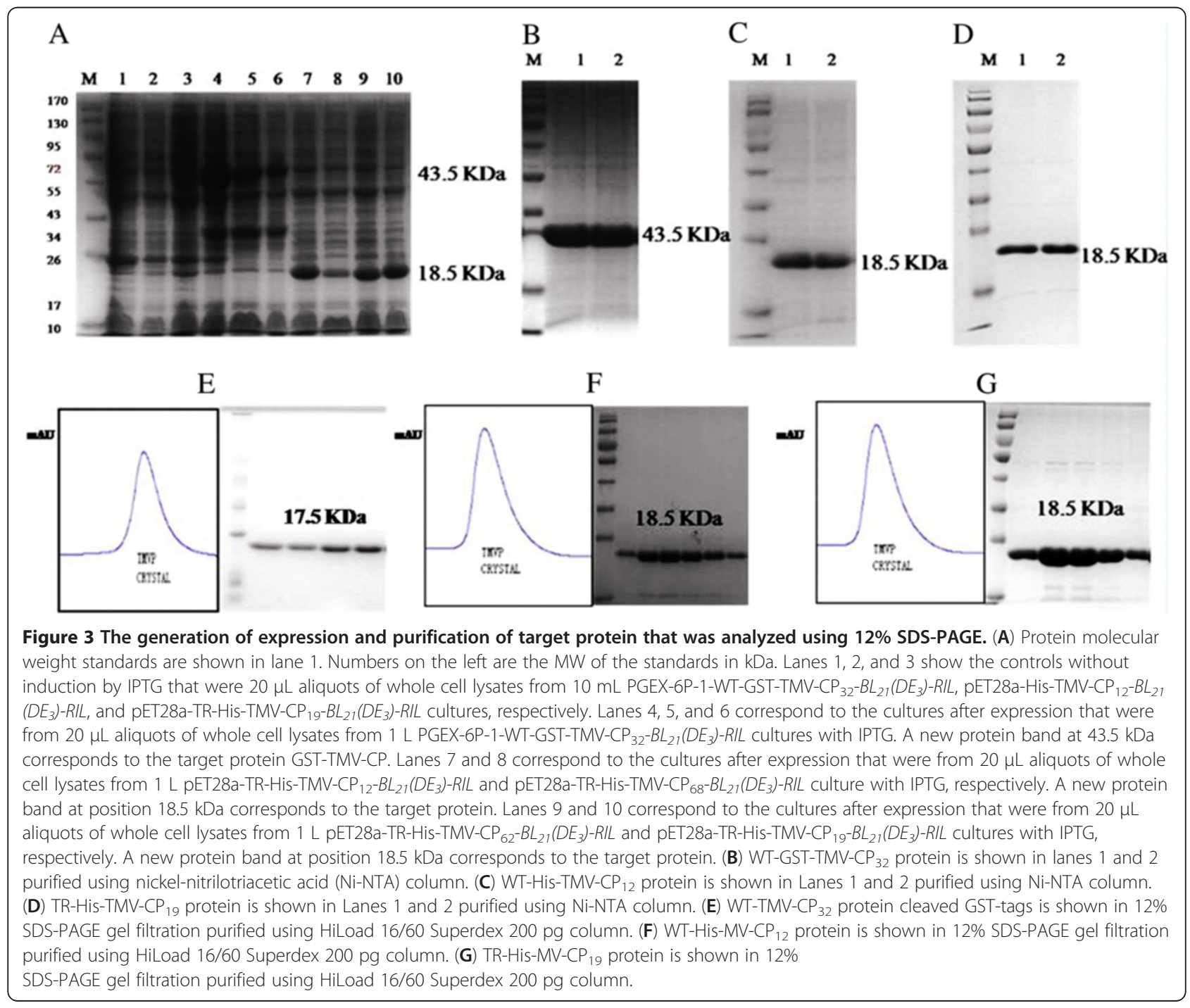


cDNA as template. The following series of genetic fragments, four amino acids truncated at the $\mathrm{C}$-terminus of WT-His-TMV-CP 12 , (TR-His-TMV-CP ${ }_{19}$ ), three amino acids truncated at the N-terminus of WT-His-TMV$\mathrm{CP}_{12}$ and four amino acids truncated at the C-terminus of WT-His-TMV-CP ${ }_{12}$ (TR-His-TMV-CP ${ }_{62}$ ), three amino acids truncated at the N-terminus of WT-His-TMV$\mathrm{CP}_{12}$, and five amino acids truncated at the C-terminus of WT-His-TMV-CP ${ }_{12}$ (TR-His-TMV-CP 68 ), were also amplified by PCR. Compared with the DNA marker, all the PCR products migrated as expected at approximately $500 \mathrm{bp}$, and the PCR products were marked as the WT-GST-TMV-CP 32 (Figure1A), WT-His-TMV$\mathrm{CP}_{12}$ (Figure 1B), TR-His-TMV-CP ${ }_{19}$ (Figure1C), TRHis-TMV-CP ${ }_{62}$, and TR-His -TMV-CP 68 separately.

The corresponding clones were sequenced by $\mathrm{ABI}$ Automatic DNA Sequence Machine, and the correct sequences were obtained and aligned (Figure 2). The DNA sequences of WT-GST-TMV-CP ${ }_{32}$, WT-His-TMV$\mathrm{CP}_{12}$, TR-His-TMV-CP 19 , TR-His-TMV-CP ${ }_{62}$, and TR-
His-TMV-CP 68 were similar that of WT-TMV-CP (isolated from TMV), except for the presence of short peptides incorporated at the N-terminal of TMV-CP in their DNA sequences. These correct proteins were successfully cloned to the expression host, E.coli $B L_{21}$ $\left(D E_{3}\right)-R I L$ (TakaRa), for protein expression.

\section{Confirmation of the Proteins Expressed and Purified by Gel Filtration}

Expressed proteins of WT-GST-TMV-CP 32 , WT-HisTMV-CP ${ }_{12}$, TR-His-TMV-CP 19 , TR-His-TMV-CP ${ }_{62}$, and TR-His-TMV- $\mathrm{CP}_{68}$ were initially assayed by Coomassie brilliant blue method in a small scale experiment in which the final volume was $10 \mathrm{~mL}$ (Figure 3A).The protein products including the whole cell lysates and the target proteins were confirmed by $12 \%$ sodium dodecyl sulfate (SDS) polyacrylamide gel electrophoresis (PAGE). The molecular mass of WT-GST-TMV-CP 32 was test by migration at approximately $43.5 \mathrm{kDa}$ (Figure 3B); the molecular mass of WT-His-TMV-CP 12 (Figure 3C),

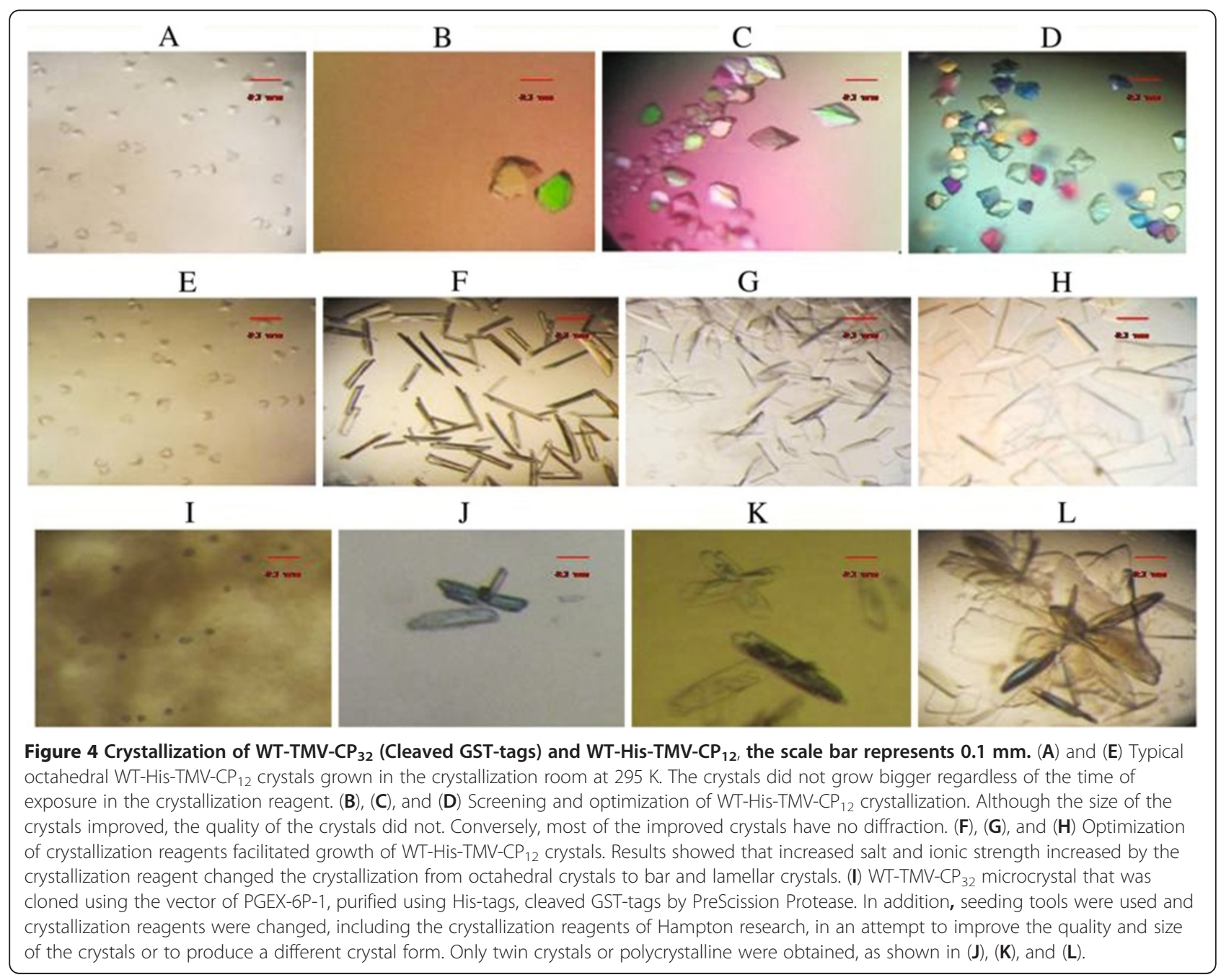


TR-His-TMV-CP 19 (Figure 3D), TR-His-TMV-CP 62 , and TR-His-TMV-CP 68 were test by in the same migration approximately at $18.5 \mathrm{kDa}$. The molecular mass of WT-TMV-CP 32 (WT-GST-TMV-CP 32 cleaved GSTtags) was test by migration at approximately $17.5 \mathrm{kDa}$ (Figure 3E), and the molecular mass of TR-His-TMV$\mathrm{CP}_{12}$ (Figure 3F) and TR-His-TMV-CP 19 (Figure 3G) were test by in the same migration at approximately $18.5 \mathrm{kDa}$.

\section{Disk state of TR-His-TMV-CP 19 in Solution}

In the size exclusion chromatography, the retention volume of N-His-TMV-CP 19 protein under $20 \mathrm{mM}$ Sodium Phosphate buffer and $100 \mathrm{mM}$ Sodium Chloride solution ( $\mathrm{PH} 8.0)$ was the oligomeric state (dimmers and monomers), and the retention volume of TR-His-TMV-CP 19 was transformed to disks mostly after dialyzing against $0.2-0.3 \mathrm{~mol} / \mathrm{L}$ ammonium sulfate and $0.1 \mathrm{~mol} / \mathrm{L}$ Tris ( $\mathrm{PH} 8.0$ ) solution at room temperature for more than 10 hr. The disk state of TR-His-TMV-CP 19 was confirmed by the map of SEC (Figure 6A) and Native-PAGE simultaneously (Figure 6B and Figure 6C).

\section{Identification and Diffraction of Crystals}

Macromolecular crystals were grown in crystallization buffers with high levels of supersaturation, often reaching several hundred percent. WT-TMV-CP 32 , WTHis-TMV-CP 12 , TR-His-TMV-CP 62 , TR-His-TMV-CP 68 crystals (Figure 4) were cultured by using Index Screen (Hampton research) and ammonium sulfate buffers. These crystals were optimized by seeding method, but high resolution crystals were not obtained.

On the contrary, TR-His-TMV-CP 19 crystals (Figure 5) (protein concentration: $14 \mathrm{mg} / \mathrm{mL}$ ) with $3.0 \AA$ resolution were obtained in $0.25 \mathrm{~mol} / \mathrm{L}$ ammonium sulfate and 0.1 $\mathrm{mol} / \mathrm{L}$ Tris solution at $295 \mathrm{~K}, \mathrm{PH} 7.7$ (Figure 6), and the Four-layer aggregate disk structure of TR-His-TMV$\mathrm{CP}_{19}$ was solved.

TMV-CP has been available as a recombinant protein expressed in E.coli for more than 20 years [37,38]. The incorporation of His-tags at the C-terminal of TMV-CP has been reported recently by introducing His-tags into TMV-CP to facilitate their purification [39]. To date, however, no one has reported on the crystallization of recombinant TMV-CP connecting peptides expressed in $E$. coli, except on the residues of chemical modification of TMV-CP [26,40-43]. These recombinant proteins connecting with peptides often did not affect the biological activity of the engineered proteins, located at the exterior of the TMV-CP disks. To obtain high resolution crystals, the expression vectors containing TMV-CP

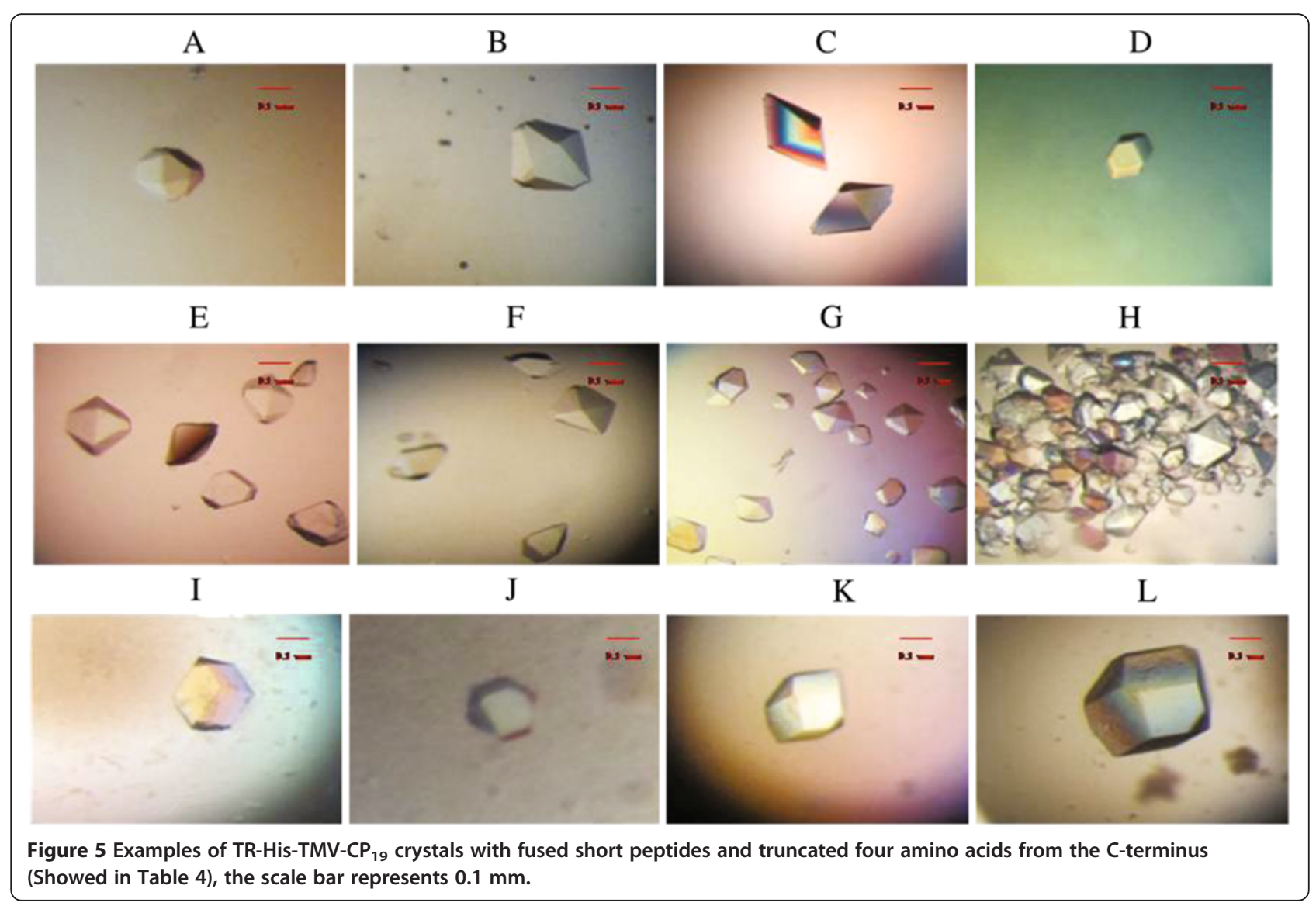




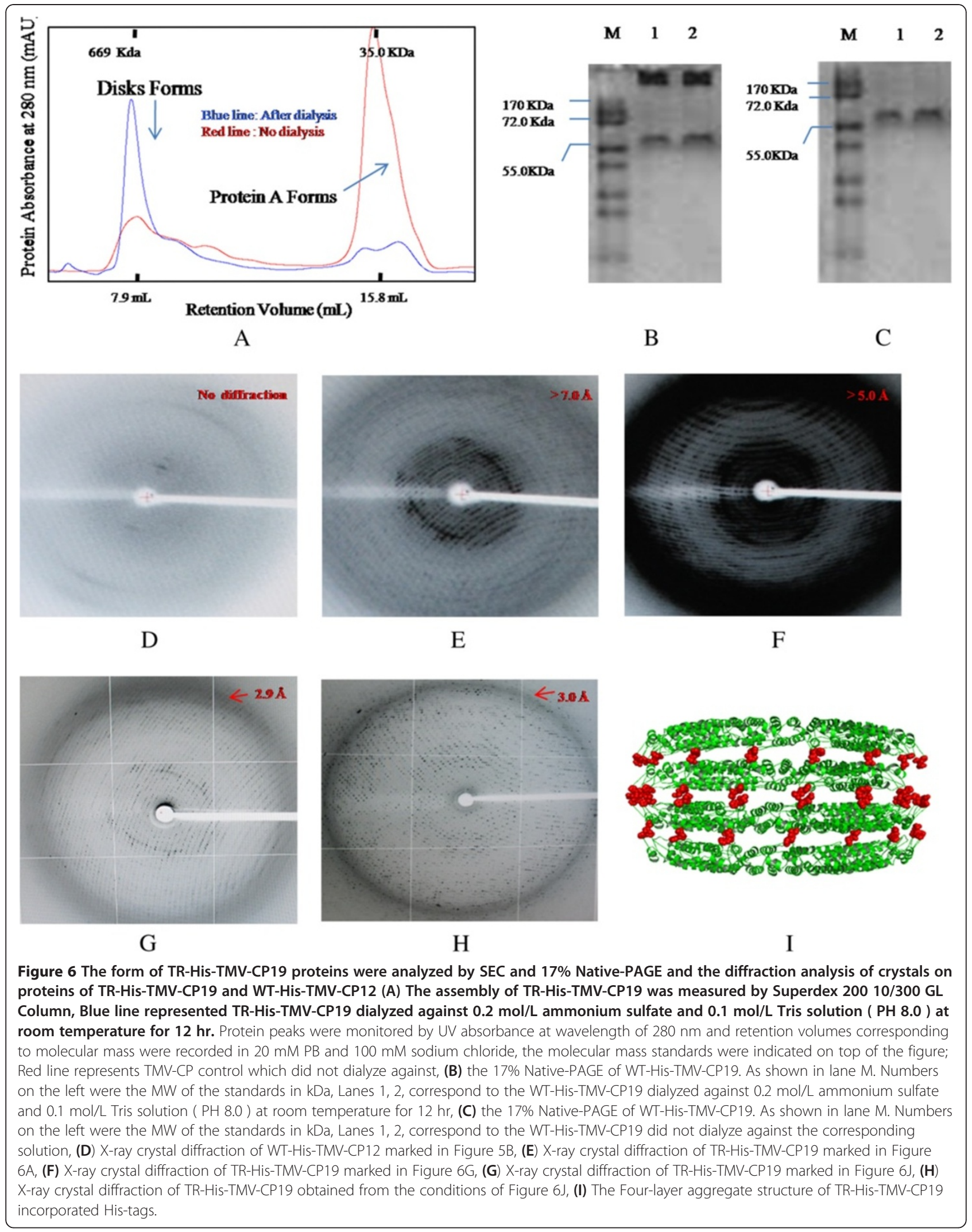




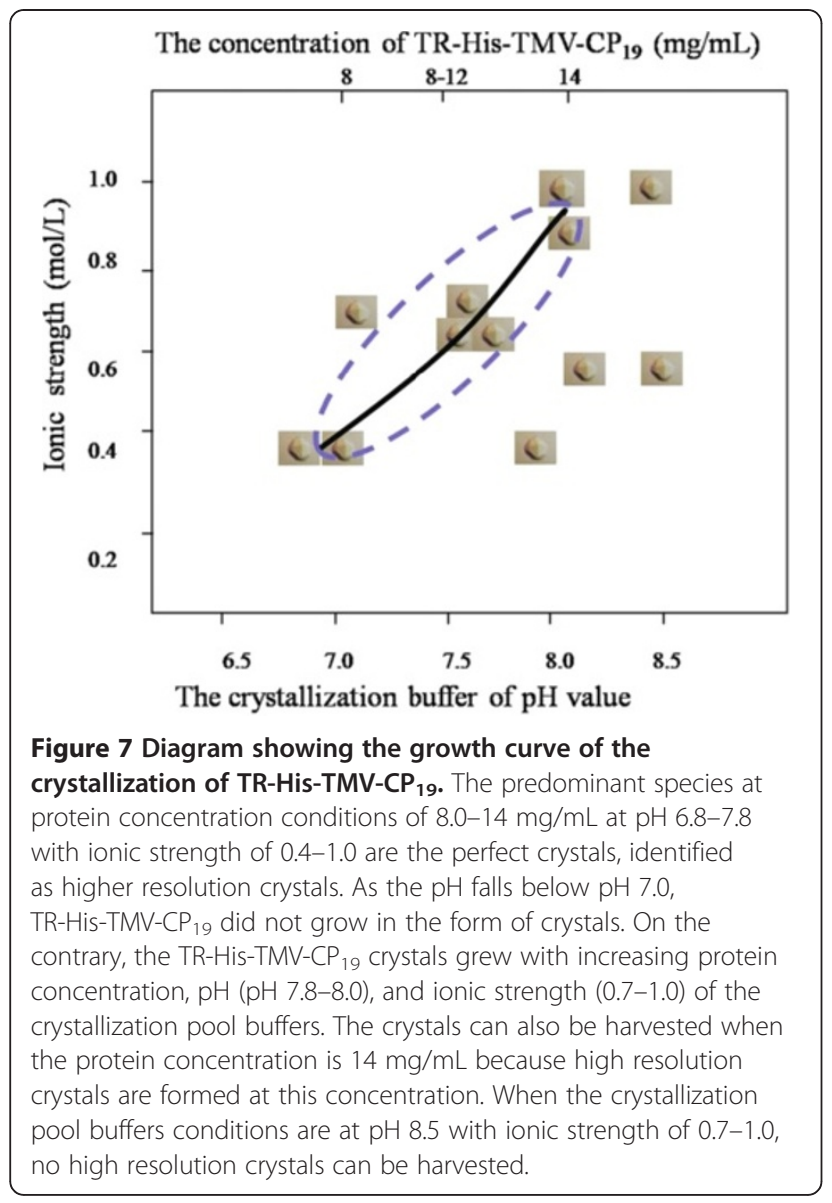

fragments were first constructed and expressed. An attempt was made to harvest the WT-His-TMV-CP ${ }_{12}$ fragments by using thrombin cleavage to cleave His-tags. His-tags were not cleaved when the proportion of thrombin cleavage and recombinant proteins was increased from 1:1 to 8:1. Subsequently, another genetically engineered WT-GST-TMV-CP 32 was constructed and expressed. Compared with His-tags, the GST-tags were easily cleaved by PreScission Protease. The crystals of WT-TMV-CP ${ }_{32}$ and WT-His-TMV-CP 12 were grown in ammonium sulfate buffers and commercial crystallization reagents simultaneously. No high resolution crystals were formed in the hanging drops when the proportion of WT-TMV-CP 32 to crystallization solution was $1: 1$. Only tiny octahedral WT-His-TMV-CP 12 crystals were grown in the crystallization room at $295 \mathrm{~K}$. No matter how long the growth time was, the crystals did not grow bigger in the crystallization buffers and commercial crystallization reagents. To maintain the physical properties of WT-His-TMV-CP 12 according to the crystalline structure of WT-TMV-CP (the amino acids at the terminal of WT-TMV-CP were flexibly) (PDB codes 1EI7 and 1VTM), three kinds of WT-HisTMV-CP ${ }_{12}$ truncated amino acids at the C-terminal (TR-His-TMV-CP 19 , TR-His-TMV-CP ${ }_{62}$, TR-His-TMV$\mathrm{CP}_{68}$ ) were constructed, expressed, purified and formed $20 \mathrm{~S}$ disks. And then the crystals of TR-His-TMV-CP 19 appeared when the protein concentration $(20 \mathrm{mmol} / \mathrm{L}$ orthophosphate and $100 \mathrm{mmol} / \mathrm{L}$ sodium chloride, $\mathrm{pH}$ 8.0 , at $297 \mathrm{~K}$ for $12 \mathrm{hr}$ ) is $8.0-14 \mathrm{mg} / \mathrm{mL}$ and crystallization pool solution ( $\mathrm{pH} 7.7$ ) consisting of 0.1 $\mathrm{mol} / \mathrm{L}$ ammonium sulfate and $0.1 \mathrm{~mol} / \mathrm{L}$ Tris at $295 \mathrm{~K}$ for $24 \mathrm{hr}$. The increasing of the ionic strength (1.0) and $\mathrm{pH}$ of the crystallization pool buffers resulted in the appearance of TR-His-TMV-CP ${ }_{19}$ crystals in the circumstance of higher protein concentration. Compared with WT-TMV-CP, the purified protein of TR-His-TMV-CP ${ }_{19}$ was in the form of protein A (Figure 6A).

The crystals of TR-His-TMV-CP 19 were obtained at 2.9-7.0 $\AA$ resolution (Figure 6E-6H) and the crystal of WT-His-TMV-CP 12 was obtained without diffraction. A Four-layer aggregate crystal structure of TR-His-TMV$\mathrm{CP}_{19}$ was obtained by removing four amino acids at the C-terminal of His-TMV-CP and connecting short

Table 1 DNA sequences of the primers

\begin{tabular}{|c|c|c|}
\hline serial number & Name & Primers \\
\hline Primer $_{C D N A}$ & TMV-cDNA & 5'-TCGACATAGGGACATCTTC-3' \\
\hline Primer $_{1}^{\mathrm{a}, \mathrm{c}}$ & WT-TMV-CP-FOR & 5'-GGAATTCCATATGTCTTACAGTATCACTACTCC-3' \\
\hline Primer ${ }_{2}^{\mathbf{b}, \mathbf{d}}$ & WT-TMV-CP-REV & 5'- CCGCTCGAGTCAAGTTGCAGGACCAGAGG-3' \\
\hline Primer $_{3}^{\mathbf{b}}$ & TR-TMV-CP-FOR & 5'-CGGGATCCATGTCTTACAGTATCACTACTCC-3' \\
\hline Primer, ${ }_{6}^{\mathrm{a}, \mathrm{d}, \mathrm{e}}$ & TR-His-TMV-CP-FOR & 5'-GGAATTCCATATGATCACTACTCCATCACAGTTCG-3' \\
\hline Primere & TR-His-TMV-CP-REV & 5'-CCGCTCGAGTCAACCAGAGGTCCAAACCAA-3' \\
\hline Primerc & TR-His-TMV-CP-REV & 5'-CCGCTCGAGTCAAGTTGCAGGACCAGAGG-3' \\
\hline
\end{tabular}

${ }^{a}$ The WT-His-TMV-CP 12 fragment was amplified by using primer ${ }_{1}$ and primer $_{2}$.

${ }^{\text {b The WT-GST-TMV-CP }} 32$ fragment was amplified by using primer ${ }_{3}$ and primer $_{2}$.

'The TR-His-TMV- $\mathrm{CP}_{19}$ fragment was amplified by using primer ${ }_{1}$ and primer $_{9}$.

${ }^{\text {d The TR-His-TMV- } \mathrm{CP}_{62} \text { fragment was amplified by using primer }}{ }_{6}$ and primer $_{2}$.

'The TR-His-TMV- $\mathrm{CP}_{68}$ fragment was amplified by using primer $_{6}$ and primer $_{8}$. 
Table 2 Protein building blocks used or referenced herein

\begin{tabular}{|c|c|c|}
\hline Building block & Origin & Abbreviation \\
\hline Wild type TMV coat protein & N. tabacum $\mathrm{K}_{326}$ & WT-TMV-CPa \\
\hline Wild type TMV coat protein with GST tags & E. coliBL ${ }_{21}\left(D E_{3}\right)-R / L$ & WT-GST-TMV-CP 32 \\
\hline Wild type TMV coat protein with His tags & E. coliBL $L_{21}\left(D E_{3}\right)-R I L$ & WT-His-TMV-CP ${ }_{12}^{c}$ \\
\hline Truncated 19 TMV coat protein with His tags & E. coliBL ${ }_{21}\left(D E_{3}\right)-R I L$ & TR-His-TMV-CP ${ }_{19}{ }^{d}$ \\
\hline Truncated 62 TMV coat protein with His tags & E. coliBL $L_{21}\left(D E_{3}\right)-R I L$ & TR-His-TMV-CP 62 e \\
\hline Truncated 68 TMV coat protein with His tags & E. coliBL ${ }_{21}\left(D E_{3}\right)-R I L$ & TR-His-TMV-CP $68{ }^{f}$ \\
\hline
\end{tabular}

The wild type TMV-CP was purified from N. tabacum $\mathrm{K}_{326}$.

${ }^{\text {b }}$ The wild type TMV-CP expressed and purified from reconstructed prokaryotic expression vector PGEX-6P-1-TMV-CP 32 that was expressed in competent cell $B L_{21}\left(D E_{3}\right)-R I L$.

'The wild type TMV-CP expressed and purified from reconstructed prokaryotic expression vector pET28a-TMV-CP 12 that was expressed in competent cell $B L_{21}\left(D E_{3}\right)-R I L$.

${ }^{\mathbf{d}}$ The truncated TMV-CP expressed and purified from reconstructed prokaryotic expression vector pET28a-TMV-CP 19 that was expressed in competent cell $B L_{21}\left(D E_{3}\right)-R I L$.

${ }^{\mathbf{e}}$ The truncated TMV-CP expressed and purified from reconstructed prokaryotic expression vector pET28a-TMV-CP 62 that was expressed in competent cell $B L_{21}\left(D E_{3}\right)-R I L$.

${ }^{\mathbf{f}}$ The truncated TMV-CP expressed and purified from reconstructed prokaryotic expression vector pET28a-TMV-CP 68 that was expressed in competent cell $B L_{21}\left(D E_{3}\right)-R I L$.

peptides at the N-terminal of His-TMV-CP (TR-HisTMV-CP 19 ). A diagram of the growth curve of TR-His$\mathrm{TMV}-\mathrm{CP}_{19}$ crystallization was drawn (Figure 7).

Compared with the crystals of WT-TMV-CP (isolated from TMV particles), the Propagation, purification and acquisition the macromolecular crystals of TR-HisTMV-CP 19 from E.coli were very facile process. By investigating, it was found that the crystals of WT-His$\mathrm{TMV}-\mathrm{CP}_{12}$ had close relationships with protein concentration, ionic strength and $\mathrm{PH}$ of the solution. After truncating four amino acids at the C-terminal of WTHis-TMV-CP 12 , a Four-layer aggregate structure of TRHis-TMV- $\mathrm{CP}_{19}$ was determined at $3.0 \AA$ resolution by using the technique of Hanging-drop vapor diffusion and seeding methods, but the high resolution crystals of WT-TMV-CP 32 , WT-His-TMV-CP 12 , TR-His-TMV-CP ${ }_{62}$, and TR-His-TMV-CP 68 did not obtain.

\section{Conclusions}

The crystallization and stability of recombinant WTTMV-CP were influenced by various factors such as the charge, isoelectric point, hydrophilicity of hybrid CP, and especially the length of the amino sequence. Based on the crystallization methods of WT-TMV-CP (isolated from TMV particles), the crystals of TR-His-TMV-CP (TR-His-TMV-CP 19 , TR-His-TMV-CP 62 , TR-His-TMV$\mathrm{CP}_{68}$ ) were grown in the crystallization buffers as mentioned above. The crystals of TR-His-TMV-CP 19 were grown by the technique of Hanging-drop vapor diffusion and seeding methods with crystallization reagents including several kinds of ammonium sulfate and Tris solutions. A map of the growth curve of the crystallization of TR-His-TMV-CP ${ }_{19}$ was drawn. In this map, the proteins of 20 s disk form of TR-His-TMV-CP 19 $(8.0-14 \mathrm{mg} / \mathrm{mL})$ were firstly prepared in solutions $(\mathrm{pH}$ 8.0) containing $20 \mathrm{mmol} / \mathrm{L}$ orthophosphate and 100 $\mathrm{mmol} / \mathrm{L}$ sodium chloride and then dialyzed against $0.2-$ $0.3 \mathrm{~mol} / \mathrm{L}$ ammonium sulfate and $0.1 \mathrm{~mol} / \mathrm{L}$ Tris solutions ( $\mathrm{PH} 8.0$ ) at $277 \mathrm{~K}$ for $12 \mathrm{hr}$. The corresponding crystals were grown in crystallization pool solutions containing $0.1-0.3 \mathrm{~mol} / \mathrm{L}$ ammonium sulfate and $0.1 \mathrm{~mol} / \mathrm{L}$ Tris at $\mathrm{pH}$ 6.5-8.5 by the technique of Hanging-drop

Table 3 The crystallization solutions of ammonium sulfate

\begin{tabular}{|c|c|c|c|}
\hline Sample & Protein concentration and buffer ${ }^{a}$ & Crystallization buffer $^{b}$ & $\begin{array}{l}\text { Temperature } \\
\text { (K) }\end{array}$ \\
\hline $\begin{array}{l}\text { WT-TMV-CP } 32 \\
\text { (cleaved GST) }\end{array}$ & $\begin{array}{l}8-14 \mathrm{mg} / \mathrm{mL}, 20 \mathrm{mmol} / \mathrm{L} \text { sodium phosphate buffer, } \\
100 \mathrm{mmol} / \mathrm{L} \text { sodium chloride, } \mathrm{pH} 8.0\end{array}$ & $\begin{array}{l}0.10-0.35 \mathrm{~mol} / \mathrm{L} \text { ammonium sulfate, } 0.1 \mathrm{~mol} / \mathrm{L} \\
\text { Tris buffer, } \mathrm{pH} 6.5-8.5\end{array}$ & $277 / 295$ \\
\hline WT-His-TMV-CP 12 & $\begin{array}{l}\text { 8-14 mg/mL, } 20 \mathrm{mmol} / \mathrm{L} \text { sodium phosphate buffer, } \\
100 \mathrm{mmol} / \mathrm{L} \text { sodium chloride, } \mathrm{pH} 8.0\end{array}$ & $\begin{array}{l}0.10-0.35 \mathrm{~mol} / \mathrm{L} \text { ammonium sulfate, } 0.1 \mathrm{~mol} / \mathrm{L} \\
\text { Tris buffer, } \mathrm{pH} 6.5-8.5\end{array}$ & $277 / 295$ \\
\hline TR-His-TMV-CP 19 & $\begin{array}{l}\text { 8-14 mg/mL, } 20 \mathrm{mmol} / \mathrm{L} \text { sodium phosphate buffer, } \\
100 \mathrm{mmol} / \mathrm{L} \text { sodium chloride, } \mathrm{pH} 8.0\end{array}$ & $\begin{array}{l}0.10-0.35 \mathrm{~mol} / \mathrm{L} \text { ammonium sulfate, } 0.1 \mathrm{~mol} / \mathrm{L} \\
\text { Tris buffer, } \mathrm{pH} 6.5-8.5\end{array}$ & $277 / 295$ \\
\hline TR-His-TMV-CP 68 & $\begin{array}{l}\text { 8-14 mg/mL, } 20 \mathrm{mmol} / \mathrm{L} \text { sodium phosphate buffer, } \\
100 \mathrm{mmol} / \mathrm{L} \text { sodium chloride, } \mathrm{pH} 8.0\end{array}$ & $\begin{array}{l}0.10-0.35 \mathrm{~mol} / \mathrm{L} \text { ammonium sulfate, } 0.1 \mathrm{~mol} / \mathrm{L} \\
\text { Tris buffer, } \mathrm{pH} 6.5-8.5\end{array}$ & $277 / 295$ \\
\hline TR-His-TMV-CP 62 & $\begin{array}{l}\text { 8-14 mg/mL, } 20 \text { mmol/L sodium phosphate buffer, } \\
100 \mathrm{mmol} / \mathrm{L} \text { sodium chloride, } \mathrm{pH} 8.0\end{array}$ & $\begin{array}{l}0.10-0.35 \mathrm{~mol} / \mathrm{L} \text { ammonium sulfate, } 0.1 \mathrm{~mol} / \mathrm{L} \\
\text { Tris buffer, } \mathrm{pH} 6.5-8.5\end{array}$ & $277 / 295$ \\
\hline
\end{tabular}

\footnotetext{
a The buffers were provided with filter membrane.
}

b The buffers were provided with filter membrane. 
vapor at 277 and $295 \mathrm{~K}$. Seeding methods were performed at $295 \mathrm{~K}$ after 1-7 d, the good macromolecular crystals appeared under different conditions. 2.9-7.0 resolution of TR-His-TMV-CP 19 (concentration $14 \mathrm{mg} / \mathrm{mL}$ ) macromolecular crystals were obtained in crystallization pool solution consisting of $0.25 \mathrm{~mol} / \mathrm{L}$ ammonium sulfate and $0.1 \mathrm{~mol} / \mathrm{L}$ Tris at $\mathrm{pH}$ 7.7. Then, using the same method, the crystals of WT-His-TMV-CP ${ }_{12}$ without resolution and some tiny WT-TMV-CP 32 crystals, were also obtained by series of seeding experiments. It was showed from the experiment that: the genetically engineered proteins of TR-His-TMV-CP ${ }^{19}$ could grow high resolution crystals. Hence, the present investigations suggest that the $\mathrm{C}$-terminal of TMV-CP was unstable for crystallization buffer, and the amino acids at the Cterminus were hypothesized to be very flexible. Additionally, the inserted sites of short peptides of TMV-CP could access the grown crystals. Short peptides have a positive influence on the stability of the biophysical properties of TMV-CP. Compared with WT-TMV-CP isolated from TMV particles, this recombinant protein of TR-His-TMV-CP ${ }^{19}$ is easy to purify and grow crystals. Thus, the latter can be applied to structural biology and structure-based drug design.

\section{Methods}

TMV (common strain) was isolated from N. tabacum $K_{326}$ leaves infected by TMV, which were cultivated in the Greenhouse of Center for Research and Development of Fine Chemicals of Guizhou University, and purified by the method described by Gooding [44], and modified by Shire [16,45]. TMV-CP was prepared by Scheel [18]. TMV-RNA was extracted from purified virus by treating with phenol and SDS [46-48]. In order to obtain the generation of full-length viral cDNA sequence, TMV-RNA was reverse transcribed using primer $_{\mathrm{CDNA}}$ (Table 1) in 50

Table 4 Examples of TR-His-TMV-CP 19 crystals in Figure 5

\begin{tabular}{|c|c|c|c|c|}
\hline Examples & Protein Concentration & Crystal Conditions & Crystal appearance & Resolutions \\
\hline A & $\begin{array}{l}8.0 \mathrm{mg} / \mathrm{mL}(20 \mathrm{mmol} / \mathrm{L} \text { sodium } \\
\text { phosphate buffer, } 100 \mathrm{mmol} / \mathrm{L} \text { sodium } \\
\text { chloride, } \mathrm{pH} \text { 8.0) }\end{array}$ & $\begin{array}{l}0.1 \mathrm{~mol} / \mathrm{L} \text { ammonium sulfate } \\
\text { and } 0.1 \mathrm{~mol} / \mathrm{L} \text { Tris } / \mathrm{HCl}, \mathrm{pH} \\
6.8\end{array}$ & $\begin{array}{l}\text { The typical dodecahedral crystals were rapid } \\
\text { growth (approximately } 24 \mathrm{hr} \text { ) at } 295 \mathrm{~K}\end{array}$ & $>7.0 \AA$ \\
\hline B & $\begin{array}{l}8.0 \mathrm{mg} / \mathrm{mL}(20 \mathrm{mmol} / \mathrm{L} \text { sodium } \\
\text { phosphate buffer, } 100 \mathrm{mmol} / \mathrm{L} \text { sodium } \\
\text { chloride, } \mathrm{pH} 8.0)\end{array}$ & $\begin{array}{l}0.1 \mathrm{~mol} / \mathrm{L} \text { ammonium sulfate } \\
\text { and } 0.1 \mathrm{~mol} / \mathrm{L} \text { Tris } / \mathrm{HCl}, \mathrm{pH} \\
\text { 7.5. }\end{array}$ & $\begin{array}{l}\text { The irregular octahedral crystals were rapid } \\
\text { growth (approximately } 24 \mathrm{hr} \text { ) at } 295 \mathrm{~K}\end{array}$ & - \\
\hline C & $\begin{array}{l}8.0 \mathrm{mg} / \mathrm{mL}(20 \mathrm{mmol} / \mathrm{L} \text { sodium } \\
\text { phosphate buffer, } 100 \mathrm{mmol} / \mathrm{L} \text { sodium } \\
\text { chloride, } \mathrm{pH} \text { 8.0) }\end{array}$ & $\begin{array}{l}0.1 \mathrm{~mol} / \mathrm{L} \text { ammonium sulfate } \\
\text { and } 0.2 \mathrm{~mol} / \mathrm{L} \text { Tris } / \mathrm{HCl}, \mathrm{pH} \\
\text { 7.0. }\end{array}$ & $\begin{array}{l}\text { The irregular octahedral crystals were rapid } \\
\text { growth (approximately } 24 \mathrm{hr} \text { ) at } 295 \mathrm{~K}\end{array}$ & - \\
\hline D & $\begin{array}{l}8.0 \mathrm{mg} / \mathrm{mL}(20 \mathrm{mmol} / \mathrm{L} \text { sodium } \\
\text { phosphate buffer, } 100 \mathrm{mmol} / \mathrm{L} \text { sodium } \\
\text { chloride, } \mathrm{pH} \text { 8.0) }\end{array}$ & $\begin{array}{l}0.3 \mathrm{~mol} / \mathrm{L} \text { ammonium sulfate } \\
\text { and } 0.1 \mathrm{~mol} / \mathrm{L} \text { Tris } / \mathrm{HCl}, \mathrm{pH} \\
\text { 7.7. }\end{array}$ & $\begin{array}{l}\text { The typical octahedral crystals were rapid } \\
\text { growth (approximately } 24 \mathrm{hr} \text { ) at } 295 \mathrm{~K}\end{array}$ & - \\
\hline$E$ & $\begin{array}{l}8.0 \mathrm{mg} / \mathrm{mL}(20 \mathrm{mmol} / \mathrm{L} \text { sodium } \\
\text { phosphate buffer, } 100 \mathrm{mmol} / \mathrm{L} \text { sodium } \\
\text { chloride, } \mathrm{pH} \text { 8.0) }\end{array}$ & $\begin{array}{l}0.2 \mathrm{~mol} / \mathrm{L} \text { ammonium sulfate } \\
\text { and } 0.1 \mathrm{~mol} / \mathrm{L} \text { Tris } / \mathrm{HCl}, \mathrm{pH} \\
6.8 .\end{array}$ & $\begin{array}{l}\text { The octahedral crystals were rapid growth } \\
\text { (approximately } 24 \mathrm{hr} \text { ) at } 295 \mathrm{~K}\end{array}$ & - \\
\hline $\mathrm{F}$ & $\begin{array}{l}8.0 \mathrm{mg} / \mathrm{mL}(20 \mathrm{mmol} / \mathrm{L} \text { sodium } \\
\text { phosphate buffer, } 100 \mathrm{mmol} / \mathrm{L} \text { sodium } \\
\text { chloride, } \mathrm{pH} \text { 8.0) }\end{array}$ & $\begin{array}{l}0.2 \mathrm{~mol} / \mathrm{L} \text { ammonium sulfate } \\
\text { and } 0.1 \mathrm{~mol} / \mathrm{L} \text { Tris } / \mathrm{HCl}, \mathrm{pH} \\
\text { 7.7. }\end{array}$ & $\begin{array}{l}\text { The octahedral crystals were rapid growth } \\
\text { (approximately } 24 \mathrm{hr} \text { ) at } 295 \mathrm{~K}\end{array}$ & - \\
\hline G & $\begin{array}{l}8.0 \mathrm{mg} / \mathrm{mL}(20 \mathrm{mmol} / \mathrm{L} \text { sodium } \\
\text { phosphate buffer, } 100 \mathrm{mmol} / \mathrm{L} \text { sodium } \\
\text { chloride, } \mathrm{pH} \text { 8.0) }\end{array}$ & $\begin{array}{l}0.2 \mathrm{~mol} / \mathrm{L} \text { ammonium sulfate } \\
\text { and } 0.1 \mathrm{~mol} / \mathrm{L} \text { Tris } / \mathrm{HCl}, \mathrm{pH} \\
6.8 \text {. }\end{array}$ & $\begin{array}{l}\text { The Octahedral crystals were rapid growth } \\
\text { (approximately } 24 \mathrm{hr} \text { ) at } 295 \mathrm{~K}\end{array}$ & $>5.0 \AA$ \\
\hline $\mathrm{H}$ & $\begin{array}{l}14 \mathrm{mg} / \mathrm{mL}(20 \mathrm{mmol} / \mathrm{L} \text { sodium phosphate } \\
\text { buffer, } 100 \mathrm{mmol} / \mathrm{L} \text { sodium chloride, } \mathrm{pH} \\
\text { 8.0) }\end{array}$ & $\begin{array}{l}0.3 \mathrm{~mol} / \mathrm{L} \text { ammonium sulfate } \\
\text { and } 0.1 \mathrm{~mol} / \mathrm{L} \text { Tris } / \mathrm{HCl}, \mathrm{pH} \\
\text { 8.0. }\end{array}$ & $\begin{array}{l}\text { The splintered off and crowded together } \\
\text { crystals were rapid growth (approximately } \\
24 \mathrm{hr} \text { ) at } 295 \mathrm{~K}\end{array}$ & - \\
\hline I & $\begin{array}{l}22 \mathrm{mg} / \mathrm{mL}(20 \mathrm{mmol} / \mathrm{L} \text { sodium phosphate } \\
\text { buffer, } 100 \mathrm{mmol} / \mathrm{L} \text { sodium chloride, } \mathrm{pH} \\
\text { 8.0) }\end{array}$ & $\begin{array}{l}0.3 \mathrm{~mol} / \mathrm{L} \text { ammonium sulfate } \\
\text { and } 0.1 \mathrm{~mol} / \mathrm{L} \text { Tris } / \mathrm{HCl}, \mathrm{pH} \\
\text { 7.7. }\end{array}$ & $\begin{array}{l}\text { The hexahedral octahedral crystals were Slow } \\
\text { growth (approximately } 7 \text { d) at } 295 \mathrm{~K}\end{array}$ & - \\
\hline$J$ & $\begin{array}{l}14 \mathrm{mg} / \mathrm{mL}(20 \mathrm{mmol} / \mathrm{L} \text { sodium phosphate } \\
\text { buffer, } 100 \mathrm{mmol} / \mathrm{L} \text { sodium chloride, } \mathrm{pH} \\
\text { 8.0) }\end{array}$ & $\begin{array}{l}0.25 \mathrm{~mol} / \mathrm{L} \text { ammonium } \\
\text { sulfate and } 0.1 \mathrm{~mol} / \mathrm{L} \text { Tris/ } \\
\mathrm{HCl}, \mathrm{pH} 7.7\end{array}$ & $\begin{array}{l}\text { The typical octahedral crystals were Slow } \\
\text { growth (approximately 1-2 d) at } 295 \mathrm{~K}\end{array}$ & $2.9-3.0 \AA$ \\
\hline K & $\begin{array}{l}22 \mathrm{mg} / \mathrm{mL} \text { ( } 20 \mathrm{mmol} / \mathrm{L} \text { sodium phosphate } \\
\text { buffer, } 100 \mathrm{mmol} / \mathrm{L} \text { sodium chloride, } \mathrm{pH} \\
\text { 8.0) }\end{array}$ & $\begin{array}{l}0.2 \mathrm{~mol} / \mathrm{L} \text { ammonium sulfate } \\
\text { and } 0.1 \mathrm{~mol} / \mathrm{L} \text { Tris } / \mathrm{HCl}, \mathrm{pH} \\
\text { 7.7. }\end{array}$ & $\begin{array}{l}\text { The dodecahedral crystals were slow growth } \\
\text { (approximately } 24 \mathrm{hr} \text { ) at } 295 \mathrm{~K}\end{array}$ & - \\
\hline$L$ & $\begin{array}{l}22 \mathrm{mg} / \mathrm{mL} \text { ( } 20 \mathrm{mmol} / \mathrm{L} \text { sodium phosphate } \\
\text { buffer, } 100 \mathrm{mmol} / \mathrm{L} \text { sodium chloride, } \mathrm{pH} \\
\text { 8.0) }\end{array}$ & $\begin{array}{l}0.2 \mathrm{~mol} / \mathrm{L} \text { ammonium sulfate } \\
\text { and } 0.1 \mathrm{~mol} / \mathrm{L} \text { Tris } / \mathrm{HCl}, \mathrm{pH} \\
\text { 7.7. }\end{array}$ & $\begin{array}{l}\text { The dodecahedral crystals were Slow growth } \\
\text { (approximately 9d) at } 295 \mathrm{~K}\end{array}$ & - \\
\hline
\end{tabular}

- stand for the crystals which didn't been diffraction by X-ray methods. 
$\mathrm{mmol} / \mathrm{L}$ Tris at $\mathrm{pH}$ 8.0, $8.0 \mathrm{mmol} / \mathrm{L}$ magnesium chloride, $75 \mathrm{mmol} / \mathrm{L}$ potassium chloride, $10 \mathrm{mmol} / \mathrm{L}$ DL-Dithiothreitol, $1.0 \mathrm{mmol} / \mathrm{L}$ dNTPs, 0.5 unit/ $\mu \mathrm{L}$ AMV reverse transcriptase (TaKaRa), and 1.0 unit/ $\mu \mathrm{L}$ RNase inhibitor (TaKaRa) for $1.5 \mathrm{hr}$ at $315 \mathrm{~K}$.

Using the generation of full-length viral cDNA sequence and the corresponding primers by the same method, TR-His-TMV-CP ${ }_{19}$, WT-GST-TMV-CP ${ }_{32}$, WTHis-TMV-CP ${ }_{12}$, TR-His-TMV-CP 62 , and TR-His-TMV$\mathrm{CP}_{68}$ sequences were amplified by $\mathrm{PCR}$ technology (Table 2).

The dsDNA of correct length was purified and identified by $1 \%$ agarose gel electrophoresis. Both plasmid pET28a (Novagen) and CP were digested with Nde I (NEB, 10 units $/ \mu \mathrm{L}$ )/Xho I (NEB, 10 units $/ \mu \mathrm{L}$ ) and cloned into the same sites in pET28a (pET28a-WT-His-TMV$\mathrm{CP}_{12}$, pET28a-TR-His-TMV-CP 19 , pET28a-TR-HisTMV-CP 62 , and pET28a-TR-His-TMV-CP 68 ). Both plasmid PGEX-6P-1 (Novagen) and CP were digested with BamH I (NEB, 10 units $/ \mu \mathrm{L}) /$ Xho I (NEB, 10 units $/ \mu \mathrm{L})$ and cloned into the same sites in PGEX-6P-1 (PGEX6P-1-WT-GST-TMV-CP 32 ). Transcription reactions were performed by using the corresponding transcription system. E. coli $B L_{21}\left(D E_{3}\right)-R I L$ (TaKaRa) cultures were transformed into vectors involving aforementioned recombinant plasmid. Expression plasmids were grown in Luria-Bertani (LB) medium containing $30 \mu \mathrm{g} / \mathrm{mL}$ kanamycin at $310 \mathrm{~K}$ until the $\mathrm{OD}_{600}$ reached $0.65-1.0$. After cooling the cultures to $289 \mathrm{~K}$, the expression product was induced by the addition of $1.0 \mathrm{mmol} / \mathrm{L}$ IPTG, and the culture was incubated for $16 \mathrm{hr}$. The cells were harvested by centrifugation and resuspended in $35 \mathrm{~mL}$ lysis buffer $(100 \mathrm{mmol} / \mathrm{L}$ sodium chloride, $50 \mathrm{mmol} / \mathrm{L}$ phosphate buffer, $\mathrm{pH} 8.0,10 \mathrm{mmol} / \mathrm{L} \beta$-mercaptoethanol). Then, the cells were thawed, lysed by supersonic device, and then centrifuged at $15000 \mathrm{rpm}$ for $30 \mathrm{~min}$ at $277 \mathrm{~K}$. The supernate was then passed through $0.22 \mathrm{~mm}$ syringe filters (Millipore) and loaded onto a Ni Sepharose High performance column (GE Healthcare, $5 \mathrm{~mL}$ ), washed with five column volumes of $40 \mathrm{mmol} / \mathrm{L}$ imidazole, and eluted with $400 \mathrm{mmol} / \mathrm{L}$ imidazole. The $\mathrm{N}$-terminal His-tags failed to cleaved with thrombin (1.0 unit $/ \mathrm{mg}$ ) and N-terminal GST-tags was cleaved successfully with PreScission Protease (1.0 unit/mg) by incubating overnight at $277 \mathrm{~K}$. The cleaved GST-tags and uncleaved His-tags were removed by the same chelating column, and the flow-through was concentrated in an Amicon Ultra centrifugal filter device (Millipore) with a $10 \mathrm{kDa}$ filter and then loaded onto a HiLoad 16/60 Superdex 200 pg column equilibrated in the dialysis solution $(20 \mathrm{mmol} / \mathrm{L}$ orthophosphate and $100 \mathrm{mmol} / \mathrm{L}$ sodium chloride, $\mathrm{pH}$ 8.0). The protein was concentrated to $5.0-25 \mathrm{mg} / \mathrm{mLfor}$ the crystallization trials by using Amicon Ultra centrifugal filter units (Millipore) with a 10
$\mathrm{kDa}$ molecular weight cutoff. The target proteins were briefly stored at $277 \mathrm{~K}$.

The purification proteins were dialyzed against the appropriate high-salt solution at room temperature to obtain the Four-layer aggregate (20S disk) [35,36,49-52]. The 20S disk form proteins were confirmed by Size Exclusion Chromatography (SEC) and Native-polyacrylamide gel Electrophoresis (Native-PAGE) method. SEC was performed at room temperature by using a calibrated Superdex 200 10/300 GL column (GE Healthcare) attached to an AKTApurifier fast protein liquid chromatography system (GE Healthcare). The column was equilibrated with a solution containing $20 \mathrm{mM}$ orthophosphate ( $\mathrm{pH} 8.0)$, $100 \mathrm{mM} \mathrm{NaCl}$ solution. Molecular mass standards (Bio-Rad) used are: Thyroglobulin $(669 \mathrm{kDa})$, Ferritin (440 kDa), BSA (67 kDa), $\beta$-lactoglobulin (35 kDa), Ribonuclease A (13.7 kDa), Cytochrome (13.6 kDa), Aprotinin $(6.51 \mathrm{kDa})$ and Vitamin B12 $(1.36 \mathrm{kDa})$. Protein was monitored by absorbance at the wavelength of $280 \mathrm{~nm}$. The crystals of purified proteins were obtained by the technique of Hanging-drop vapor diffusion. The protein concentration was $5.0-25 \mathrm{mg} / \mathrm{mL}$, and the crystallization solutions contained $0.1-0.3 \mathrm{~mol} / \mathrm{L}$ ammonium sulfate and $0.1 \mathrm{~mol} / \mathrm{L}$ Tris at PH 6.5-8.5 (Table 3) for 1-7 d at 293-298 K. The crystals (Table 4) were first soaked with cryoprotection (the reservoir solution containing an extra $30 \%$ glycerol), and then mounted and flash-frozen in liquid nitrogen [33,34]. Diffraction data were collected

Table 5 Data collection and refinement statistics of TR-His-TMV- $\mathrm{CP}_{19}$ Crystals in Figure $6 \mathrm{I}$

\begin{tabular}{|c|c|}
\hline & TR-His-TMV $\mathrm{CP}_{19}$ \\
\hline \multicolumn{2}{|l|}{ Data collection } \\
\hline Space group & $P 2,2,2$ \\
\hline \multicolumn{2}{|l|}{ Cell dimensions } \\
\hline$a, b, c(\AA)$ & $171,311,314$ \\
\hline$a, \beta, \gamma\left(^{\circ}\right)$ & $90,90,90$ \\
\hline Resolution $(\AA)$ & $50.0-3.06(3.17-3.06)$ \\
\hline$R_{\text {sym }}$ & $0.11(0.196)$ \\
\hline $1 / \sigma(I)$ & $10.1(6.4)$ \\
\hline Completeness (\%) & $99.7(99.2)$ \\
\hline Redundancy & $4.4(3.84)$ \\
\hline \multicolumn{2}{|c|}{ Refinement statistics } \\
\hline Resolution $(\AA)$ & $20.0-3.06(3.14-3.06)$ \\
\hline No. reflections & 155016 \\
\hline$R_{\text {work }} / R_{\text {free }}$ & $20.4 / 25.5$ \\
\hline No. atoms & 36918 \\
\hline B-factors & 47.9 \\
\hline \multicolumn{2}{|l|}{ R.m.s deviations } \\
\hline Bond lengths $(\AA)$ & 0.013 \\
\hline Bond angles ( ${ }^{\circ}$ ) & 1.499 \\
\hline
\end{tabular}

*Highest resolution shell is shown in parenthesis. 
at Shanghai Synchrotron Radiation Facility beamline 17U. All the X-ray data were processed by using HKL2000 program suite and converted to structure factors within the CCP4 program (Table 5).

\section{Abbreviations} \\ TMV: Tobacco mosaic virus; CP: Coat protein; His: Hexahistidine; \\ GST: Glutathione-S-transferase; Ni-NTA: Nickel-nitrilotriacetic acid; \\ dsDNA: Double-stranded DNA; cDNA: Complementary DNA; IPTG: Isopropyl \\ B-D-thiogalactopyranose; SDS: Dodecylsulfate; PAGE: Polyacrylamide gel \\ electrophoresis; Native-PAGE: Native-polyacrylamide gel Electrophoresis; \\ SEC: Size Exclusion Chromatography; WT: Wild type; TR: Truncation; Tris: Tris \\ (hydroxymethyl)aminomethane; DTT: DL-dithiothreitol; LB: Luria-Bertani; \\ E.coli: Escherichia coli; N. tabacum: Nicotiana tabacum.
}

\section{Competing interests}

The authors declare that they have no competing interests.

\section{Authors' contributions}

BAS and SY designed this study. XYL carried out the clone and protein expression studies, participated in the sequence alignment and drafted the manuscript. ZC,ZCW,MJZ and DDY performed Crystallization tests. LHJ collected and analyzed the data of genetically engineered TMV-CP crystals. BAS, SY, DYH, and ZC critically revised the manuscript. All of the authors read and approved the final version of the manuscript.

\section{Acknowledgements}

We thank Professor Chuan He from the University of Chicago and Professor Caiguang Yang from the Shanghai Institute of Materia Medica (CAS) for the crystallographic discussion and assistance. We also acknowledge user support for the beam line BL17U at the Shanghai Synchrotron Radiation Facility as well as In House X-Ray at Shanghai Institute of Materia Medica, China. The authors also wish to thank the National Key Program for Basic Research (No. 2010CB 126105) and Special Fund for Agro-scientific Research in the Public Interest (No.201203022) and the National Natural Science Foundation of China (No.21132003) and the Key Technologies R\&D Program (No. 2011BAE06B05-6) for the financial support.

Received: 1 February 2012 Accepted: 3 October 2012

Published: 21 November 2012

\section{References}

1. Caspar DLD: Assembly and stability of the tobacco mosaic virus particle. Adv Protein Chem 1963, 18:37-121.

2. Bloomer AC, Champness JN, Bricogne G, Stoden R, Klug A: Protein disk of tobacco mosaic virus at $2.8 \AA$ resolution showing the interaction within and between subunits. Nature 1978, 276:362-368.

3. Culver JN: Tobacco mosaic virus assembly and disassembly: Determinants in pathogenicity and resistance. Annu Rev Phytopathol 2002, 40:287-308

4. Harrison $\mathrm{BD}$, Wilson $\mathrm{TM}$ : Milestones in the research on tobacco mosaic virus. Philos Trans R Soc B 1999, 354:521-529.

5. Scheele RB, Schuster TM: Kinetics of protein subunit interaction: simulation of a polymerized overshoot. Biopolymers 1974, 13:275-288.

6. Pattanayek $R$, Stubbs $G$ : Structure of the $U_{2}$ strain of tobacco mosaic virus refined at $3.5 \AA$ resolution using $\mathrm{x}$-ray fiber diffraction. J Mol Biol 1992, 228:516-528.

7. Stubbs G, Warren S, Holmes K: Structure of RNA and RNA binding site in tobacco mosaic virus from a $4 \AA$ map calculated from X-ray fiber diagrams. Nature 1997, 267:216-221.

8. Culver JN, Stubbs G, Dawson WO: Structure-function relationship between tobacco mosaic virus coat protein and hypersensitivity in Nicotiana sylvestris. J Mol Biol 1994, 242:130-138.

9. Namba K, Stubbs G: Structure of tobacco mosaic virus at $3.6 \AA$ Å resolution: implications for assembly. Science 1986, 231:1401-1406.

10. Klug A, Caspar DLD: The structure of simple viruses. Adv Virus Res 1960, 13:1-63.

11. Mandelkow E, Holmes KC, Gallawitz U: A new helical aggregate of tobacco mosaic virus protein. J Mol Biol 1976, 102:265-285.
12. Butler PJG, Durham ACH: Tobacco mosaic virus protein aggregation and the virus assembly. Adv Protein Chem 1977, 31:188-251.

13. Mandelkow E, Stubbs G, Warren S: Structures of the helical aggregates of tobacco mosaic virus protein. J Mol Biol 1981, 152:375-386.

14. Butler PJG: The current picture of the structure and assembly of tobacco mosaic virus. J Gen Virol 1984, 65:253-279.

15. Bloomer AC, Butler PJG: Tobacco mosaic virus structure and selfassembly. In The plant viruses. 2nd edition. Edited by Regenmortel MHV Fraenkel-Conrat H. New York: Chapman and Hall; 1986:19-57.

16. Shire SJ, Steckert JJ, Adams ML, Schuster TM: Kinetics and mechanism of tobacco mosaic virus assembly: direct measurement of relative rates of incorporation of 4S and 20S protein. Proc Natl Acad Sci USA 1979, 76(6):2745-2749.

17. Caspar DLD, Namba K: Switching in the self-assembly of tobacco mosaic virus. Adv Biophys 1990, 26:157-185

18. Scheele RB, Lauffer MA: Acid-base titrations of tobacco mosaic virus and tobacco mosaic virus protein. Biochemistry 1967, 6:3076-3081.

19. Durham ACH, Finch JT, Klug A: States of aggregation of tobacco mosaic virus protein. Nature New Biol 1971, 229:37-42.

20. Durham ACH, Klug A: Polymerisation of tobacco mosaic virus protein and its control. Nature New Biol 1971, 229:42-46.

21. Durham ACH: The cause of irreversible polymerization of tobacco mosaic virus protein. FEBS Lett 1972, 25:147-152.

22. Stubbs G: Molecular structures of viruses from the tobacco mosaic virus group. Semin Virol 1990, 1:405-412.

23. Bhyravbhatla B, Stanley JW, Caspar DLD: Refined atomic model of the four-layer aggregate of the tobacco mosaic virus coat protein at $2.4 \AA$ resolution. Biophys J 1998, 74:604-615.

24. Namba K, Caspar DLD, Stubbs G: Enhancement and simplification of macromolecular images. Biophy J 1998, 53:469-475.

25. Namba K, Pattanegek R, Stubbs G: Visualization of protein RNA interaction in a virus: Refined structure of TMV at $2.9 \AA$ resolution by X-ray fiber diffraction. J Mol Biol 1989, 208:307-325.

26. Dedeo MT, Duderstadt KE, Berger JM, Francis MB: Nanoscale protein assemblies from a circular permutant of the tobacco mosaic virus. Nano Lett 2010, 10:181-186.

27. Sachse C, Chen JZ, Coureux PD, Stroupe ME, Fändrich M, Grigorieff N: Highresolution electron microscopy of helical specimens: A fresh look at tobacco mosaic virus. J Mol Biol 2007, 371:812-835.

28. Clare DK, Orlova EV: $4.6 \AA$ cryo-EM reconstruction of tobacco mosaic virus from images recorded at $300 \mathrm{keV}$ on a $4 \mathrm{k} \times 4 \mathrm{k} C \mathrm{CD}$ camera. J Struct Biol 2010, 171:303-308.

29. Ge P, Zhou ZH: Hydrogen-bonding networks and RNA bases revealed by cryo electron microscopy suggest a triggering mechanism for calcium switches. Proc Natl Acad Sci 2011, 1008:9637-9642.

30. Okada Y: Molecular assembly of tobacco mosaic virus in vitro. Adv Biophys 1986, 22:95-145.

31. Raghavendra K, Adams ML, Schuster TM: Tobacco mosaic virus protein aggregates in solution: Structural comparison of $20 \mathrm{~S}$ aggregates with those near conditions for disk crystallization. Biochemistry 1985, 24:3298-3304.

32. Sperling R, Klug A: States of aggregation of the Dahlemense strain of tobacco mosaic virus protein and their relation to crystal formation. $J$ Mol Biol 1975, 96:425-430.

33. Raghavendra KDM, Salunke DLD, Caspar STM: Disk aggregates of tobacco mosaic virus coat protein in solution: electron microscopy observations. Biochemistry 1986, 25:6276-6279.

34. Raghavendra K, Kelly JA, Khairallah L, Schuster TM: Structure and function of disk aggregates of the coat protein of tobacco mosaic virus. Biochemistry 1988, 27:7583-7588.

35. Correia JJ, Shire S, Yphantis DA, Schuster TM: Sedimentation equilibrium measurements of the intermediate-size tobacco mosaic virus protein polymers. Biochemistry 1985, 24:3292-3297.

36. Durham ACH: Structures and roles of the polymorphic forms of tobacco mosaic virus protein. I. Sedimentation studies. J Mol Biol 1972, 67:289-305.

37. Shire SJ, McKay P, Leung DW, Cachianes GJ, Jackson E, Woods WI, Raghavendra K, Khairallah L, Schuster TM: Preparation and properties of recombinant DNA rerived Tobacco Mosaic Virus Coat Protein. Biochemistry 1990, 29:5119-5126.

38. Hwang DJ, Roberts IM, Wilson TMA: Expression of tobacco mosaic virus coat protein and assembly of pseudo virus particles in Escherichia Coli. Proc Natl Acad Sci USA 1994, 91:9067-9071. 
39. Bruckman MA, Soto CM, McDowell H, Liu JL, Ratna BR, Korpany KV, Zahr OK, Blum AS: Role of hexahistidine in directed nanoassemblies of tobacco mosaic virus coat protein. Nano Lett 2011, 5(3):1606-1616.

40. Endo M, Wang H, Fujitsuka M, Majima T: Pyrene-stacked nanostructures constructed in the recombinant tobacco mosaic virus rod scaffold. Chem Eur J 2006, 12:3735-3740.

41. Lee SY, Choi J, Royston E, Janes DB, Culver JN, Harris MT: Deposition of platinum clusters on surface-modified tobacco mosaic virus. J Nanosci Nanotechnol 2006, 6:974-981.

42. Miler RA, Presley AD, Francis MB: Self-assembling light-harvesting systems from synthetically modified tobacco mosaic virus coat proteins. J Am Chem Soc 2007, 129:3104-3109.

43. Schlick TL, Ding Z, Kovacs EW, Francis MB: Dual-Surface modification of the tobacco mosaic virus. J Am Chem Soc 2005, 127:3718-3723.

44. Gooding GV, Hebert TT: A simple technique for purification of tobacco mosaic virus in large quantities. Phytopathologigal notes 1967, 1285-1286.

45. Shire SJ, Steckert JJ, Schuster TM: Mechanism of self assembly of tobacco mosaic virus protein. II. Characterization of the metastable polymerization nucleus and the initial stages of helix formation. $J \mathrm{Mol}$ Biol 1979, 127:487-506.

46. Fraenkel-Conrat HB, Singer, Tsugita A: Purification of viral RNA by means of bentonite. Virology 1961, 14:54-58.

47. Hebert TT: Precipitation of plant viruses by polyethylene glycol. Phytopathology 1963, 53:36.

48. Wilcockson JRH: The rapid isolation of plant virus RNAs using sodium perchlorate. J Gen Virol 1974, 23:107-111.

49. Schuster TM, Scheele RB, Adams ML, Shire SJ, Steckert JJ, Potschka M: Studies on the mechanism of assembly of tobacco mosaic virus. Biophys J 1980, 32:313-329.

50. Schuster TM, Scheele RB, Khairallah LH: Mechanism of self-assembly of tobacco mosaic virus protein. I. Nucleation-controlled kinetics of polymerization. J Mol Biol 1979, 127:461-468.

51. Schuster TM, Scheele RB, Adams ML, Shire SJ, Steckert JJ, Potschka M: Studies on the mechanism of assembly of tobacco mosaic virus. Biophys J 1980, 10:313-317.

52. Kegel WK, Schoot P: Physical regulation of the self-assembly of tobacco mosaic virus coat protein. Biophys J 2006, 91:1501-1512

\section{Submit your next manuscript to BioMed Central and take full advantage of:}

- Convenient online submission

- Thorough peer review

- No space constraints or color figure charges

- Immediate publication on acceptance

- Inclusion in PubMed, CAS, Scopus and Google Scholar

- Research which is freely available for redistribution 